\title{
The Potential Growing Areas for Argania spinosa (L.) Skeels (Sapotaceae) in Argentinean Drylands
}

\author{
Silvia L. Falasca $\left(\mathbb{D},{ }^{1}\right.$ Sandra Pitta-Alvarez $\left(\mathbb{D},{ }^{2,3}\right.$ and Ana Ulberich ${ }^{4}$ \\ ${ }^{1}$ Climate and Water Institute, INTA, Las Cabañas y Los Reseros, s/n, Castelar, Buenos Aires, Argentina \\ ${ }^{2}$ Laboratorio de Cultivo Experimental de Plantas y Microalgas, Departamento de Biodiversidad y Biología Experimental, Facultad de \\ Ciencias Exactas y Naturales, Universidad de Buenos Aires, Buenos Aires, Argentina \\ ${ }^{3}$ Instituto de Micología y Botánica (INMIBO), Universidad de Buenos Aires-CONICET, Buenos Aires, Argentina \\ ${ }^{4}$ Centro de Investigaciones y Estudios Ambientales (CINEA), Facultad de Ciencias Humanas (FCH), Universidad Nacional del Centro \\ de la Provincia de Buenos Aires (UNICEN), Campus Universitario, Paraje Arroyo Seco, s/n, Tandil, Argentina
}

Correspondence should be addressed to Silvia L. Falasca; slfalasca@gmail.com

Received 21 December 2017; Accepted 19 March 2018; Published 2 May 2018

Academic Editor: Othmane Merah

Copyright (c) 2018 Silvia L. Falasca et al. This is an open access article distributed under the Creative Commons Attribution License, which permits unrestricted use, distribution, and reproduction in any medium, provided the original work is properly cited.

\begin{abstract}
The argan (Argania spinosa L.) tree is indigenous to southwestern Morocco. Successful introduction of this species in Argentina depends on the degree of climate similarity in the natural area compared to new areas with agroclimatic suitability. Based on international bibliography, the authors outlined an agroclimatic zoning model for this tree in Argentina. To determine agroclimatic suitability, the average climatic data of all the meteorological stations (1981-2010) were analyzed. Climatological characteristics of its region of origin were considered to evaluate the requirements and biometeorological conditions. The maps were obtained using a series of previously interpolated bioclimatic variables. The agroclimatic indices, which determine different classes of suitability, were integrated in a Geographic Information System (GIS) to create thermal and moisture regions. The resulting maps were superimposed to determine the agroclimatic zoning. Eight classes of agroclimatic suitability under dry-subhumid, semiarid, and arid climatic conditions were delineated. There are no optimal zones for the argan tree in Argentina. This work can be updated by further incorporation of complementary information. Argan tree is a promising dryland crop for farmers in semiarid and arid climates of Argentina. This model may be applied in any part of the world, using the agroclimatic limits presented in this paper.
\end{abstract}

\section{Introduction}

The argan (Argania spinosa L.) belongs to the Sapotaceae family and it is the only species of the genus Argania. It is a little-known tree indigenous to intramontane areas, with very low average rainfall, in southwestern Morocco. The plant is distributed across five Moroccan provinces (the most important ones are Agadir, Essaouira, Toroudant, and Tiznit), in arid and semiarid ecosystems, with Atlantic influence, between $29^{\circ}$ and $32^{\circ}$ of north latitude $[1,2]$. Some isolated populations can be found northeast of Morocco, 400 to $700 \mathrm{~km}$ away from the main ones: in Berkane in the northern slope of the mountain Beni-Snassen, close to the Mediterranean coast ( $800 \mathrm{ha})$, and in the Bou-Dreg plains (Kariat Arakmane), in the eastern Rif of the high valleys of Oued Grou, close to Rabat (50 ha) [2]. The argan tree is disseminated from Safi (north) to the Drâa River (south), and isolated populations extend as far as Tindouf, well inside the Western Sahara. Starting in Essaouira and extending to Goulmime, and from the High Atlas to the Atlantic Ocean, it covers more than 828,000 ha [3]. According to [4], it appears in subspontaneous form in the Sahara, between Djebel Ouarkziz and the Hamada of Tindouf (Algeria), in humid microhabitats. It can also be found in certain parts of the Spanish Levante in Alicante. These isolated populations are considered relicts of a wider distribution in the past [5].

Edible argan oil is obtained from lightly toasted kernels, and it is becoming increasingly popular in gastronomy due to its exotic aroma and fruit-like flavor, reminiscent of a mixture of nuts, hazelnuts, and sesame seeds. The color is darker and the odor stronger than argan cosmetic oil because of the previous toasting of the kernels. Edible argan oil has several 
sterols that are uncommon in other edible vegetable oils, such as scotenol (48\%), which has antitumoral and anticancer properties, and spinasterol (42\%), a compound that reduces intestinal cholesterol absorption. The white seeds contain up to $50 \%$ of light brown oil, and oil production ranges between 1000 and 2000 tons per year. The ratio of total unsaturated to total saturated fatty acids is around $4: 5$. Polyunsaturated fatty acids constitute approximately $80 \%$ of argan oil, and $30 \%$ of it is linoleic acid. This composition is particularly adept for nutritional, cosmetic, and medicinal uses. Argan oil is rich in vitamin $\mathrm{E}$ and it has been reported to lower cholesterol levels, stimulate blood circulation, facilitate digestion, and strengthen the body's natural defenses [6]. The dietary and nutritional properties of argan oil are superior to those of extravirgin olive oil. The oil is also used for illumination and soap.

The tree is also popular as a shade tree and it is useful for soil conservation and windbreaks. After the oil is extracted, the residue from the kernels constitutes a thick chocolatecolored paste called "amlou," with a flavor similar to that of peanut butter.

The tree is an important source of forage for sheep, goats, and cattle, but horses reject it. It contains the haemolytic saponin sapoarganine, which is slightly toxic but does not harm ruminants. However, if dairy cattle are fed with the cake, it contaminates the milk, and this may cause diarrhoea in children. Goats digest the fleshy part of the fruit, but discharge the nut because of its hard shell. The nuts are later collected by farmers to produce oil.

The wood is hard, heavy, and durable, and it results in good charcoal and firewood. The nut-shells are also burned for cooking. Argan wood cannot be destructed by insects, and it has been used for centuries in carpentry, charcoal, construction, and utensils at local level.

The international price of argan oil has stimulated the idea of cultivating A. spinosa in regions far from its original geographic center [7]. This could affect the argan oil business in Morocco and defeat the efforts initiated to save the argan forests. For this reason, the Moroccan government seeks to obtain a Geographical Indication (GI) on argan oil [8]. A GI would mean that only the argan oil prepared from seeds collected in Morocco, with the appropriate rules of production, could be sold as such under that name [7]. According to [7], the oil of this species was first reported in the thirteenth century by the botanist, scientist, pharmacist, and physician Ibn al-Baitar. These researchers maintain that argan tree is one of the few surviving relict-breed species of the Tertiary Period, which spanned from 65 million to 1.8 million years ago. Currently, the tree can be found in the south of Morocco, west of Algeria, north of Western Sahara, and north of Mauritania [9]. It was introduced for cultivation into Algeria, Israel, Kuwait, Libya, the semiarid Southeast Spain [10], and Mexico [6].

The argan forest is particularly sensitive to climate change and it was ignored as a specific biotope for a long time. In 1998, it was declared a Biosphere Reserve by UNESCO [11]. In some regions, it is already damaged, and its future is endangered by prolonged drought periods and desertification. The tree is in threat of extinction due to clearance, poor germination quality, and the use of the timber as fuel. According to [12], in the period 1970-2007, argan tree density decreased 44.5\%. Recently, strict conservation measures have been implemented to prevent its disappearance [13].

Occasionally, new crops with attractive properties and exploitation potential capture the attention of both public and private sectors. Some of these new crops ameliorate the effects of increased atmospheric $\mathrm{CO}_{2}$ (greenhouse effect), which turns fertile lands into deserts by increasing temperature and producing drought [15]. The resulting boom of this particular species can lead to large investments and campaigns promoting the need for its domestication and industrial scale commercialization. However, research on these plants is usually scarce because they are commonly wild nondomesticated species. Farmers tend to be cautious and avert the risks involved in developing new crops. Investors, on the other hand, frequently fail because they lack adequate information concerning the risks and uncertainties related to these ventures. For instance, they sometimes put at risk the sustainability of the ecosystem where implantation is purported, or they ignore the agroclimatic requirements of the species.

The aim of this work was to design an agroclimatic zoning model to define the potential growing areas for Argania spinosa in Argentina.

\section{Materials and Methods}

2.1. Study Area. The area studied was the Argentine Republic. The country borders to the north with Bolivia, Brazil, and Paraguay; to the south with Chile and the Atlantic Ocean; to the east with Brazil, Uruguay, and the Atlantic Ocean; and to the west with Chile (Figure 1).

Argentina's climatic diversity is remarkable due to both its vast territory and distinct geographic factors that influence the climatic characteristics of the different regions. One of these factors is the great latitudinal development: Argentina expands from $21^{\circ} 46^{\prime}$ (province of Jujuy) in the north to $55^{\circ} 03$ in Cape San Pío (province of Tierra del Fuego), in the south. The extreme eastern limit of the country is located at $53^{\circ} 38^{\prime} \mathrm{W}$, in the town of Bernardo de Irigoyen (province of Misiones).

The limit between the subhumid and semiarid zones is represented by the $500 \mathrm{~mm}$ isohyet. The area situated between 500 and $1000 \mathrm{~mm} /$ year presents a subhumid climate, and the climate is humid when it exceeds $1000 \mathrm{~mm}$. To the west of the $500 \mathrm{~mm}$ isohyet, the moisture gradient provided by rainfall from the South Atlantic anticyclone decreases and the climate turns dry-subhumid, semiarid, and, finally, arid.

2.2. Ecological Requirements. According to [13], the argan tree prospers in desert or arid (Bw), steppe or semiarid (Bs) climates, between 20 and $32^{\circ}$ latitude. The tree has several mechanisms that restrain water loss: it reaches the deepest layers of soil during dry season, it can close its stomata during the day, and it has water reservoirs in its trunk and branches [10].

The argan is a species that can be cultivated in drylands in regions where annual rainfalls are in the $200-300 \mathrm{~mm}$ range, with a minimum of $100 \mathrm{~mm}$ and a maximum of 


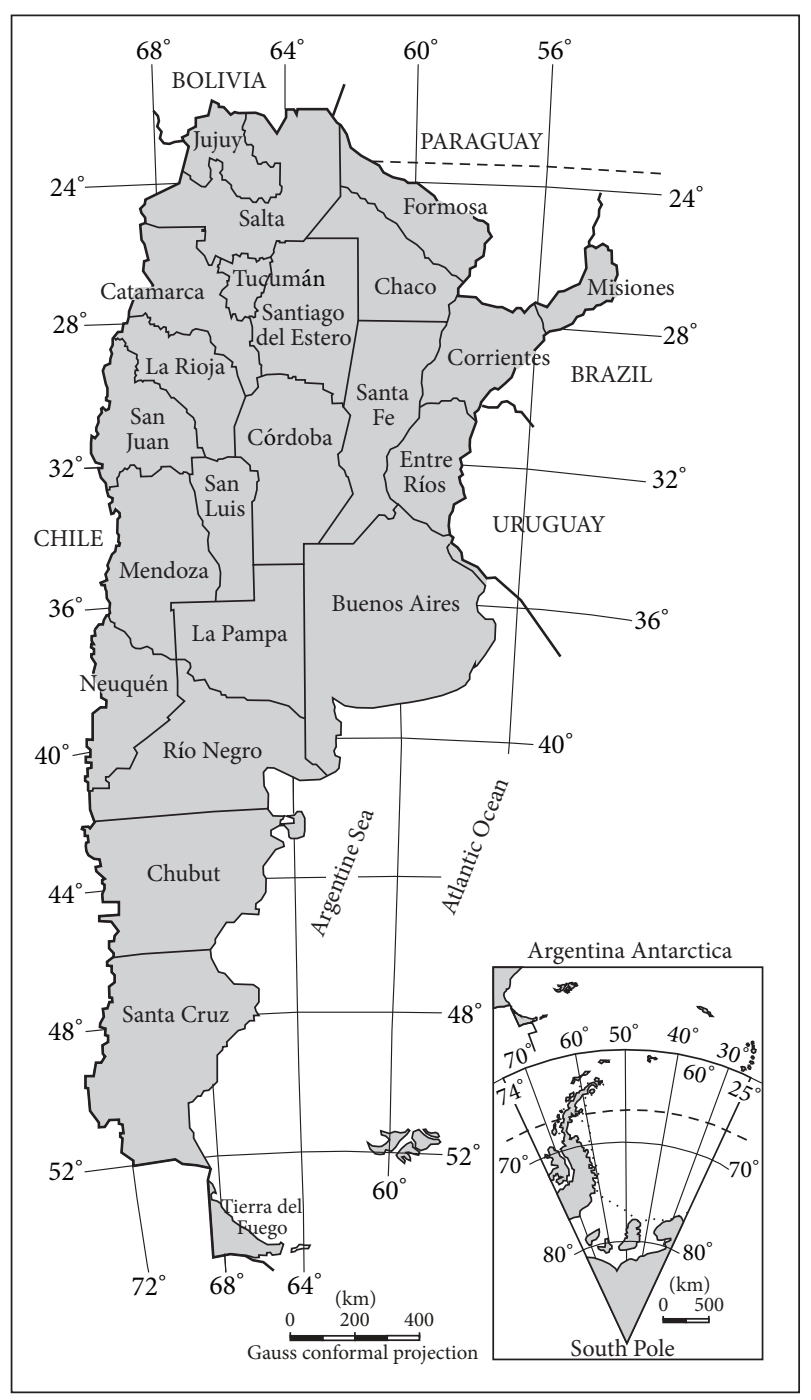

FIgURE 1: Argentina’s political map.

$400 \mathrm{~mm}$ [13]. The critical period, as far as water is concerned, is between the preflowering and ripening phases, and this usually corresponds to the period with the highest rain scarcity in the original areas.

Germination does not occur with temperatures below $10^{\circ} \mathrm{C}$, and the optimum germination temperature is $25^{\circ} \mathrm{C}$ [16], with night temperatures above $21^{\circ} \mathrm{C}$ [17]. The tree flourishes in areas where annual mean temperatures fluctuate between 18 and $20^{\circ} \mathrm{C}$. Best growth is observed with temperatures in the $20-30^{\circ} \mathrm{C}$ range, with a minimum of $10^{\circ} \mathrm{C}$ and a maximum of $35^{\circ} \mathrm{C}$, although it can tolerate maximum temperatures of $50^{\circ} \mathrm{C}$. According to [13], the tree dies with frosts of $-2^{\circ} \mathrm{C}$, although according to [18] it can tolerate $-5^{\circ} \mathrm{C}$.

The species needs neutral soils ( $\mathrm{pH}$ of 6.5 to 7.5 ) and, although soil quality is not an issue, drifting sands and waterlogged soils must be avoided. Argan is a saline-sensitive plant $[14,19]$ and adult trees do not adapt to the higher salinity associated with dry areas.
Flowering occurs mainly in spring, with great differences among individuals, and with a secondary peak in autumn. As a result, fruit production extends over a long period and fruits can be found in different ripening phases from April to September [3] in the north hemisphere.

2.3. Climate of the Original Area. Considering that the species has not yet been introduced into Argentina, the climate of its original area was studied in detail. Morocco's climate is Mediterranean, with Atlantic and Saharan influences. The climate is characterized by two gradients: decreasing precipitation with increasing temperature from north to south and from west to east [20]. Currently, the argan tree is found in an intramontane area with very low average rainfall. The land is bordered by the Sahara, the High Atlas, and the Anti-Atlas Mountains between Essaouira and Agadir Ida Outanane and open to the Atlantic on the west side. The altitudinal range of the argan tree extends from sea level up to $1,300-1,500 \mathrm{~m}$.

The annual rainfall varies from $250 \mathrm{~mm}$ in Safi to $400 \mathrm{~mm}$ in Agadir. From the Souss plain to the Anti-Atlas Mountains, annual precipitation is in the 250 to $150 \mathrm{~mm}$ range. To the south, in desert areas, precipitations are considerably lower than $100 \mathrm{~mm}$ [2].

In the coastal areas where argan trees grow, there are temperate oceanic influences with moderate temperatures (annual average in Agadir is $18.5^{\circ} \mathrm{C}$; minimum temperature of coldest month: $7.4^{\circ} \mathrm{C}$ ) and low annual and daily thermal amplitude [14].

In the mountains and inside the continent, the thermal amplitude reaches higher values and the minimum temperatures of the coldest month fluctuate from $3^{\circ} \mathrm{C}$ to $7^{\circ} \mathrm{C}$. The highest boundary for argan tree is close to the $3.8^{\circ} \mathrm{C}$ isotherm, which corresponds to the lower limit for snow [2]. The average maximum winter temperature ranges from $17.5^{\circ} \mathrm{C}$ to $22^{\circ} \mathrm{C}[21]$.

Most crops commonly show recognizable differences in many of their properties within their area of distribution. These are usually the result of climate variations, and even slight changes in a single climate element can wield important influences. For this reason, two extreme climatic areas were chosen to describe the "argan bioclimate."

One of these areas is Admine Forest (hereafter Coastal Browsing, $30^{\circ} 26^{\prime} 54.13^{\prime \prime} \mathrm{N}$ and $9^{\circ} 32^{\prime} 49.90^{\prime \prime} \mathrm{W}$, located in the suburbs of Agadir city, $5 \mathrm{~km}$ inland, $107 \mathrm{~m}$ of altitude), which different authors [22-24] consider as the ecological optimum for the species and the center of its distribution area. It is a region traditionally used for agriculture and livestock raising. Natural vegetation is scarce, except for the dominant A. spinosa, and the climate is temperate due to marine influence. Maximum temperatures never surpass $30^{\circ} \mathrm{C}$ and the minimum of the coldest month is never below $7^{\circ} \mathrm{C}$ [25]. Annual rainfall is scarce $(232 \mathrm{~mm})$ and concentrated from October to April.

The second area is Tassademt (hereafter Mountain), a site located $70 \mathrm{~km} \mathrm{NE}$ of Agadir in the first foothills of the Atlas Mountains, which is characterized by its extreme climatic conditions. This site was selected because it is situated in the proximity of the species' natural distribution limit. It is 
TABLE 1: Climatic characteristics of area of origin of the argan tree (elaborated by the authors based on [14]).

\begin{tabular}{|c|c|c|c|c|c|c|}
\hline City & $\begin{array}{l}\text { Geographical } \\
\text { location }\end{array}$ & $\begin{array}{l}\text { North } \\
\text { latitude }\end{array}$ & $\begin{array}{l}\text { Annual } \\
\text { minim. } \\
\text { temper. } \\
\left({ }^{\circ} \mathrm{C}\right)\end{array}$ & $\begin{array}{c}\text { Annual } \\
\text { temper. } \\
\left({ }^{\circ} \mathrm{C}\right)\end{array}$ & $\begin{array}{l}\text { Annual } \\
\text { maxim. } \\
\text { temper. } \\
\left({ }^{\circ} \mathrm{C}\right)\end{array}$ & $\begin{array}{c}\text { Annual } \\
\text { rainfall } \\
(\mathrm{mm})\end{array}$ \\
\hline Agadir & Seaside & $30^{\circ} 25^{\prime}$ & 13.4 & 18.4 & 23.4 & 291.9 \\
\hline Ait Melloul & Souss plain & $32^{\circ} 00^{\prime}$ & 13.0 & 18.4 & 23.0 & 233.5 \\
\hline Argana & $\begin{array}{c}\text { Southern } \\
\text { slope of High } \\
\text { Atlas } \\
\text { Mountains }\end{array}$ & $30^{\circ} 45^{\prime}$ & 9.1 & 18.9 & 28.7 & 421.7 \\
\hline Ait Baha & $\begin{array}{l}\text { Northern } \\
\text { slope of } \\
\text { Anti-Atlas } \\
\text { Mountains }\end{array}$ & $30^{\circ} 30^{\prime}$ & 10.7 & 20.1 & 29.4 & 223.0 \\
\hline Essaouira & Seaside & $31^{\circ} 30^{\prime}$ & 14.6 & 17.3 & 20.0 & 342.6 \\
\hline
\end{tabular}

an open forest where argan is the predominant vegetation type and broad gaps are covered with a grass community. Scarce and scattered spiny shrubs are the main woody vegetation. The climate is more extreme than in Agadir, with a distinct continental character. Monthly average temperatures are $40^{\circ} \mathrm{C}$ in summer and $3^{\circ} \mathrm{C}$ in winter; but they can drop to $-5^{\circ} \mathrm{C}$. Summer is particularly harsh because temperatures are inordinately high and rainfall is scant $(385 \mathrm{~mm})$ and almost totally absent.

Table 1 shows some climatic characteristics of area of origin of the argan tree.

2.4. The Agroclimatic Zoning Model for Argan. The climate system of a particular place defines the crops that can be developed. To identify regions with appropriate bioclimatic conditions for cultivating A. spinosa, both winter and summer requirements must be considered, since resistance to frosts and drought can be the key to success. To define the suitable zones, studies must focus on whether the agroclimatic availability of an area can satisfy the biometeorological demands of this species. To achieve this, both the thermal and the moisture regime, which are fundamental climatic characteristics that affect the development of this crop, must be considered.

First, we had to identify the requirements, limits, and biometeorological tolerance and conditions to establish the potential growing areas. The climatological characteristics of the original area were analyzed, and the resulting bioclimatic indicators were extrapolated to the Argentine territory. Aspects of growth, such as development and death chances by excess or deficiency, were analyzed.

The climate of a geographic location can be depicted by long-term averages or "Normals," which are defined as 30year averages of a climate element. In this work, a set of longterm averages, covering a range of climate elements, for the period 1981 to 2010 was assembled. Geographical location, mean annual rainfall, and temperature records available from meteorological and agrometeorological stations within the study area were also considered. Values were averaged for each month over a 30 -year period to obtain the long-term average.
The values which best indicate the thermal requirements of this species and can be used as equivalents are the bioclimatic variables: annual mean temperature, annual mean maximum temperature, annual mean minimum temperature, winter mean maximum temperature, minimum temperature of the coldest month, mean annual minimum temperature, and annual rainfall. These were obtained by interpolating the data collected in the 125 meteorological stations across the country (National Meteorological Service).

To create the maps, a series of previously interpolated bioclimatic variables were used. Afterwards, these were processed by the Geographic Information System (GIS) tool of the Arc-GIS 9.3 program. Climatic interpolations were made using the "Interpolate to Raster" tool, within the "3D Analyst" extension of the GIS of the same program, following the Ordinary Kriging interpolation method.

Since the moisture factor was the first bioclimatic variable examined, the average yearly rainfall isohyets for the period 1981-2010 were observed. The limits were delineated by the 100 and $400 \mathrm{~mm}$ isohyets [13]. If argan tree is grown under rainfed conditions, the nonsuitable areas are those with annual precipitations below $100 \mathrm{~mm}$. However, if the purpose is production of edible oil, these areas could qualify as suitable with complementary irrigation. In the 100 to $200 \mathrm{~mm}$ and 300 to $400 \mathrm{~mm}$ interval, the area is suitable and, from 200 to $300 \mathrm{~mm}$, optimal.

The first index used to analyze the thermal factor was the annual mean temperature, measured over a period of 30 years. This index is calculated by averaging the 12 normal monthly temperatures over the 30 -year period. If temperatures fall below $18^{\circ} \mathrm{C}$ the climate is deemed too cold for the argan tree, and the area is not suitable [13]. Another index is the annual mean maximum temperature, which should surpass $23.0^{\circ} \mathrm{C}$ to ensure an appropriate thermal regime during the growing period [14].

To the extent that the species is unable to withstand cold, the annual mean minimum temperature, the winter mean maximum temperature, and the minimum temperature of the coldest month were analyzed. The annual mean minimum temperature, an index that represents the minimum daily 
TABLE 2: Classes of agroclimatic suitability and limits for each class.

\begin{tabular}{|c|c|c|c|c|c|c|c|}
\hline $\begin{array}{l}\text { Agroclimatic } \\
\text { suitability }\end{array}$ & $\begin{array}{c}\text { Annual } \\
\text { temper. } \\
\left({ }^{\circ} \mathrm{C}\right)\end{array}$ & $\begin{array}{l}\text { Annual } \\
\text { min. } \\
\text { temper. } \\
\left({ }^{\circ} \mathrm{C}\right)\end{array}$ & $\begin{array}{l}\text { Winter } \\
\text { max. } \\
\text { temper. } \\
\left({ }^{\circ} \mathrm{C}\right)\end{array}$ & $\begin{array}{c}\text { Minim } \\
\text { temper. } \\
\text { coldest } \\
\text { month } \\
\left({ }^{\circ} \mathrm{C}\right)\end{array}$ & $\begin{array}{c}\text { Mean } \\
\text { annual } \\
\text { min. } \\
\text { temper. } \\
\left({ }^{\circ} \mathrm{C}\right)\end{array}$ & $\begin{array}{c}\text { Annual } \\
\text { max. } \\
\text { temper. } \\
\left({ }^{\circ} \mathrm{C}\right)\end{array}$ & $\begin{array}{c}\text { Annual } \\
\text { rainfall } \\
(\mathrm{mm})\end{array}$ \\
\hline Nonsuitable & $<18$ & $<10$ & $<17.5$ & $<3.8$ & $<-5$ & $<23.0$ & $<100$ \\
\hline Suitable $_{1}$ & $>18$ & $>10$ & $17.5-22.0$ & $3.8-7.0$ & $>-5$ & $>23.0$ & $100-200$ \\
\hline Suitable $_{2}$ & $>18$ & $>10$ & $17.5-22.0$ & $3.8-7.0$ & $>-5$ & $>23.0$ & $300-400$ \\
\hline Very suitable & $>18$ & $>10$ & $17.5-22.0$ & $3.8-7.0$ & $>-5$ & $>23.0$ & $200-300$ \\
\hline Optimal & $>18$ & $>10$ & $17.5-22.0$ & $>7.0$ & $>-5$ & $>23.0$ & $200-300$ \\
\hline Marginal & & & $>22$ & & & & $>500$ \\
\hline
\end{tabular}

temperatures registered over 30 years, reveals the intensity of minimum temperatures and, according to [14], it should surpass $10.0^{\circ} \mathrm{C}$.

Argentina's winter lasts from June to August. According to [21], the winter mean maximum temperature should be higher than $17.5^{\circ} \mathrm{C}$. This index represents the average of the maximum temperatures from June to August, over the 30year period considered.

The minimum temperature of the coldest month (in Argentina, July) is, by definition, the minimum monthly temperature occurrence over a 30 -year period (normal) and it should be above $3.8^{\circ} \mathrm{C}$ [2]. In the optimal zone, the minimum temperature of the coldest month must never be below $7^{\circ} \mathrm{C}$ [25].

A very important factor is the species' resistance to cold, since it can hinder its cultivation in a specific area. Although Argentine territory extends towards the Tropic of Capricorn $\left(23^{\circ} 27^{\prime} \mathrm{S}\right)$, it lacks tropical climates. Consequently, damage by frost should be avoided when tropical species are exploited. To prevent lethal effects, the annual mean minimum temperature (that represents the long-term average daily minimum air temperature observed during a calendar month and over the year) cannot be lower than $-5^{\circ} \mathrm{C}$ [18] .

The agroclimatic zoning map was obtained by superimposing the maps related to moisture and thermal regimes. The following classes were delineated: very suitable, suitable, suitable with constraints (under dry-subhumid, semiarid, and arid regimes), suitable with constraints under irrigation, marginal, and nonsuitable.

Table 2 shows the agroclimatic indices that define each class of agroclimatic suitability. It is important to highlight that the nonsuitable areas present two or more of the constraints indicated in Table 2.

Argentina's political map, with the toponomy of the provinces, was included to aid in the identification of the classified areas with different grades of agroclimatic fitness (Figure 1).

\section{Results}

Figure 2 shows the moisture regions. Different classes of suitability were characterized: nonsuitable, marginal, suitable, and optimal. If rainfalls are below $100 \mathrm{~mm}$, the area is deemed

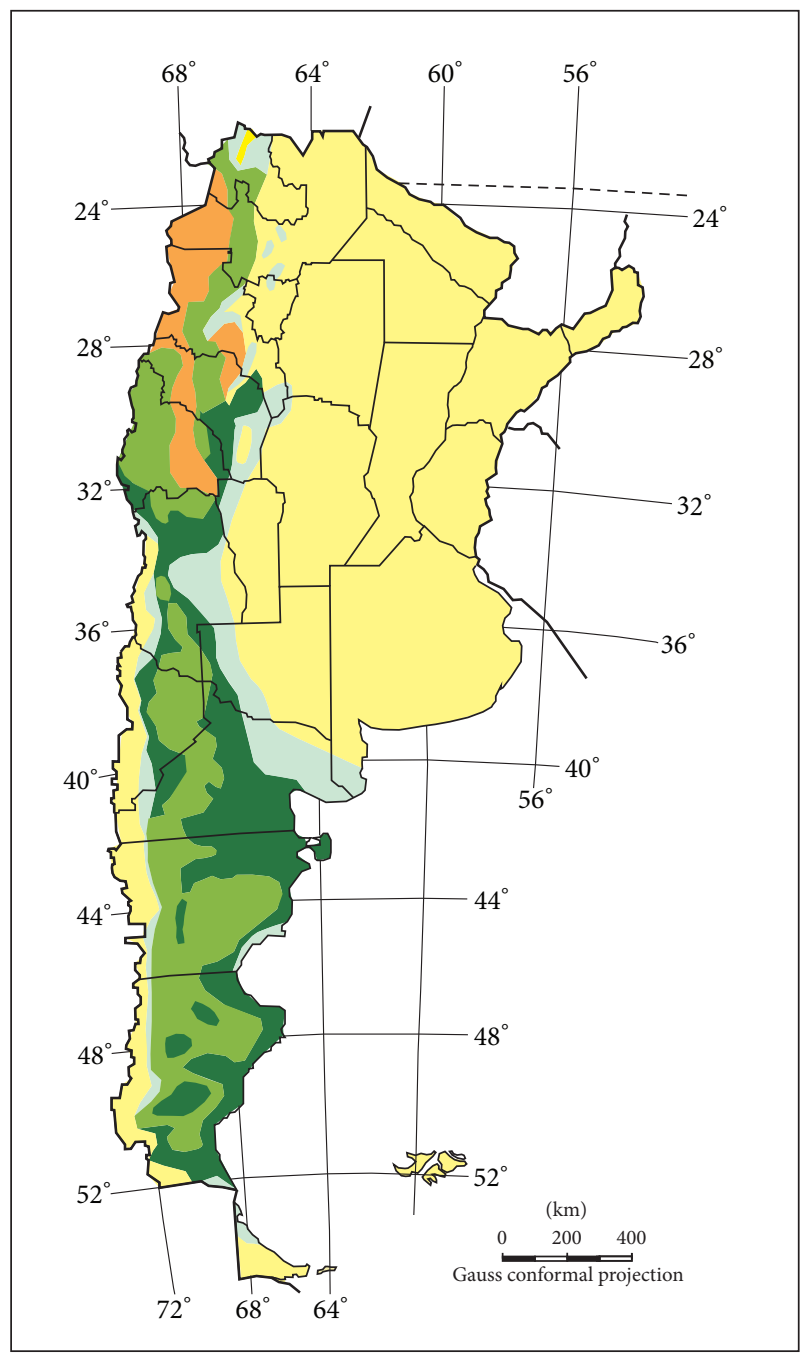

Optimal area: $201-300 \mathrm{~mm}$

Suitable area: $100-200 \mathrm{~mm}$

Suitable area: $301-400 \mathrm{~mm}$

Marginal area: $>400 \mathrm{~mm}$

Marginal area: $<100 \mathrm{~mm}$

Figure 2: Annual rainfall. 


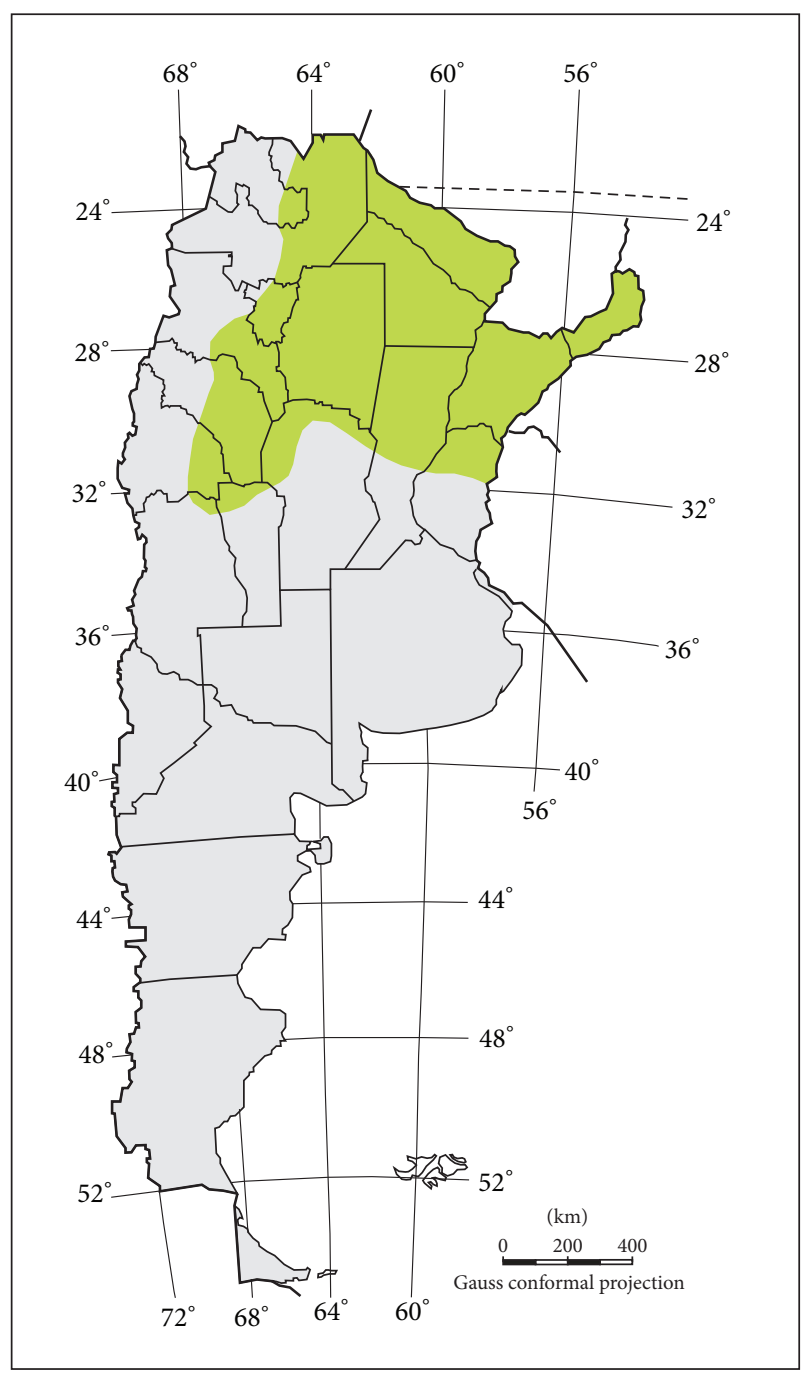

Suitable area: $>18^{\circ} \mathrm{C}$

Non suitable area: $<18^{\circ} \mathrm{C}$

FIgURE 3: Annual mean temperature.

marginal under rainfed conditions and in the $100-200 \mathrm{~mm}$ range, it is a suitable area. An optimal area can be identified to the west of the country and another one in the Patagonian region. To the east, another suitable area can be recognized, and it receives annual rainfalls in the $300-400 \mathrm{~mm}$ range. Rainfalls that exceed $400 \mathrm{~mm}$ delimit marginal areas for the argan tree.

Figure 3 presents the annual mean temperature $>18^{\circ} \mathrm{C}$. This isotherm indicates the southern limit for warm climates that can still be appropriate for tropical crops. The $18^{\circ} \mathrm{C}$ isotherm covers north and part of the center of the country. In its path, it shows an inflection towards the north owing to the Pampeanas Saws located in the provinces of Córdoba and San Luis.

Figure 4 shows the areas where the annual mean maximum temperature surpasses $23.0^{\circ} \mathrm{C}$, determining the suitable area. The $23^{\circ} \mathrm{C}$ isotherm covers the north and a large section

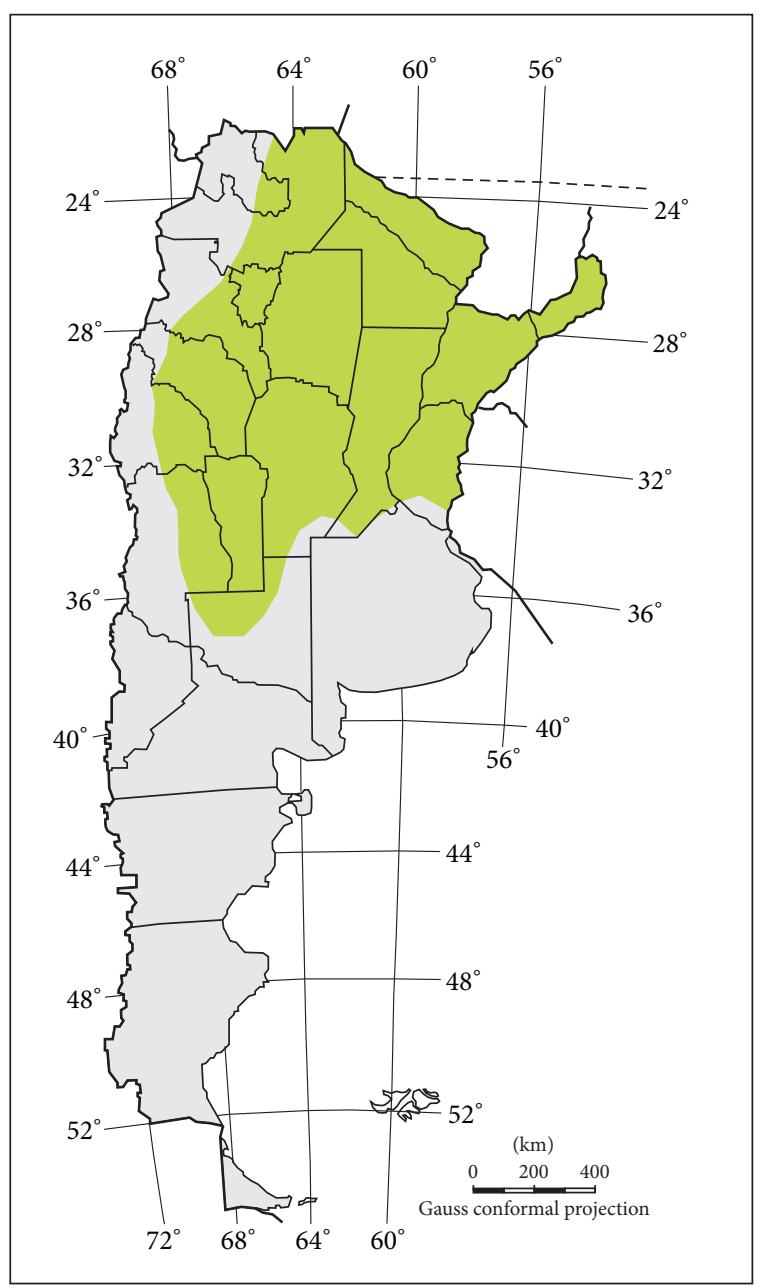

Suitable area: $>23^{\circ} \mathrm{C}$

Non suitable area: $\angle 23^{\circ} \mathrm{C}$

FIGURE 4: Annual mean maximum temperature.

of the center of the country. The great inflection towards the south in the province of La Pampa, due to the continentality factor, is noteworthy. It later diverts to the north because of the altitudinal effect imposed by the Andes Mountains. This zone, considered suitable, is influenced by the north wind year-round, which is responsible for the high temperatures over the year.

Figure 5 presents the areas where the annual mean minimum temperature is above $10^{\circ} \mathrm{C}$. The $10.0^{\circ} \mathrm{C}$ isotherm diverts to the south influenced by the oceanity factor, which is conspicuous in the province of Buenos Aires. This area, considered suitable, reveals how the incoming cold air from the Polar Front projects to the north. This is responsible for the low minimum temperatures in all the national territory.

Figure 6 shows the winter mean maximum temperature. When it is lower than $17.5^{\circ} \mathrm{C}$ a nonsuitable area is delineated; in the 17.5 to $22.0^{\circ} \mathrm{C}$ range the area is suitable, while temperatures above $22^{\circ} \mathrm{C}$ define marginal areas. The suitable areas cover the eastern and center part of the country. There 


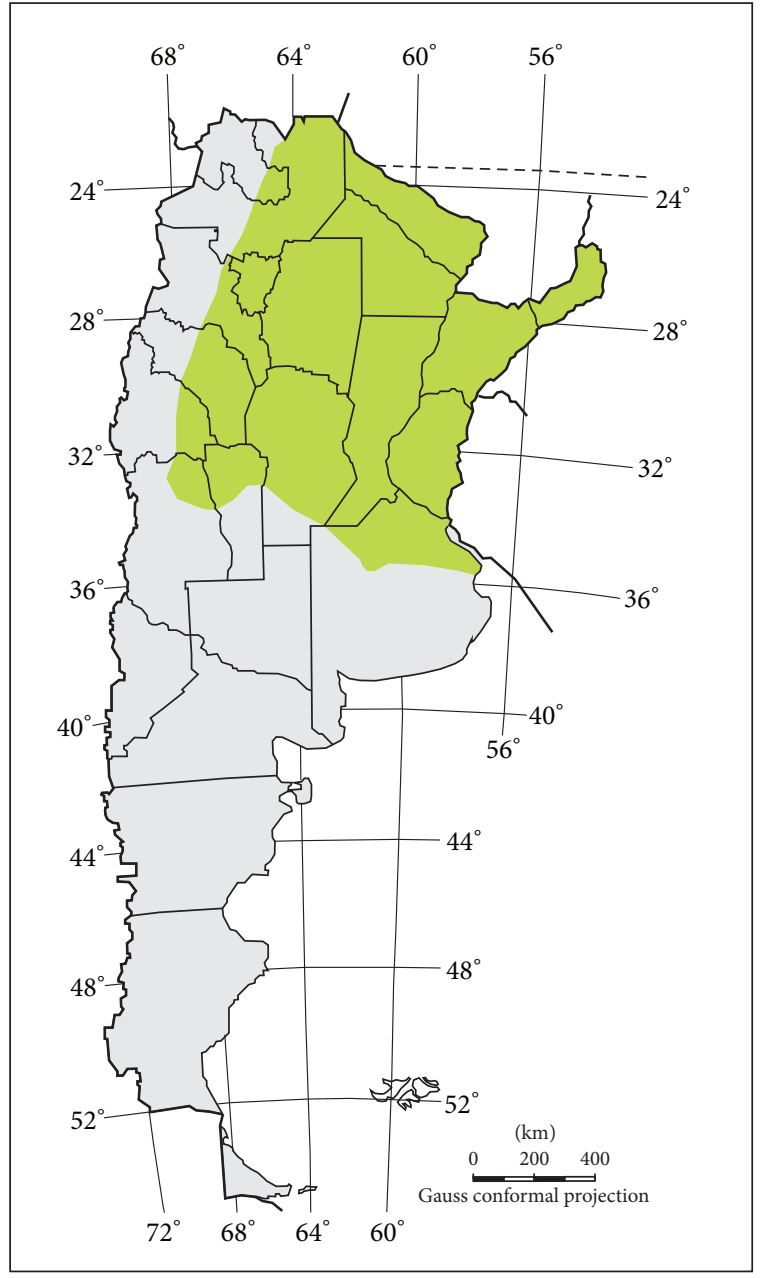

Suitable area: $>10^{\circ} \mathrm{C}$

Non suitable area: $<10^{\circ} \mathrm{C}$

Figure 5: Annual mean minimum temperature.

is a marginal area in the north due to the high winter temperatures.

Figure 7 shows the minimum temperature of the coldest month (July). The north and northeast present optimum conditions with an average temperature of $7^{\circ} \mathrm{C}$, while the suitable area (where minimum temperatures in July range from 3.8 to $7^{\circ} \mathrm{C}$ ) covers the center of the country and reaches the center of the Buenos Aires province. Nonsuitable areas, whose minimum temperature of coldest month is lower than $3.8^{\circ} \mathrm{C}$, cover the west, the center, and the Patagonian sector.

In Figure 8 the mean annual minimum temperature of $-5^{\circ} \mathrm{C}$ is shown. The suitable areas are those where the average minimum temperature is above $-5^{\circ} \mathrm{C}$. This index is a very important constraint, because lower temperatures can be lethal to argan tree. Suitable areas cover part of the north and the center of the country, and the east of Argentina.

Finally, Figure 9 (obtained by overlaying all the abovementioned maps) presents the agroclimatic zoning for the argan tree. Eight classes of suitability were delineated: very

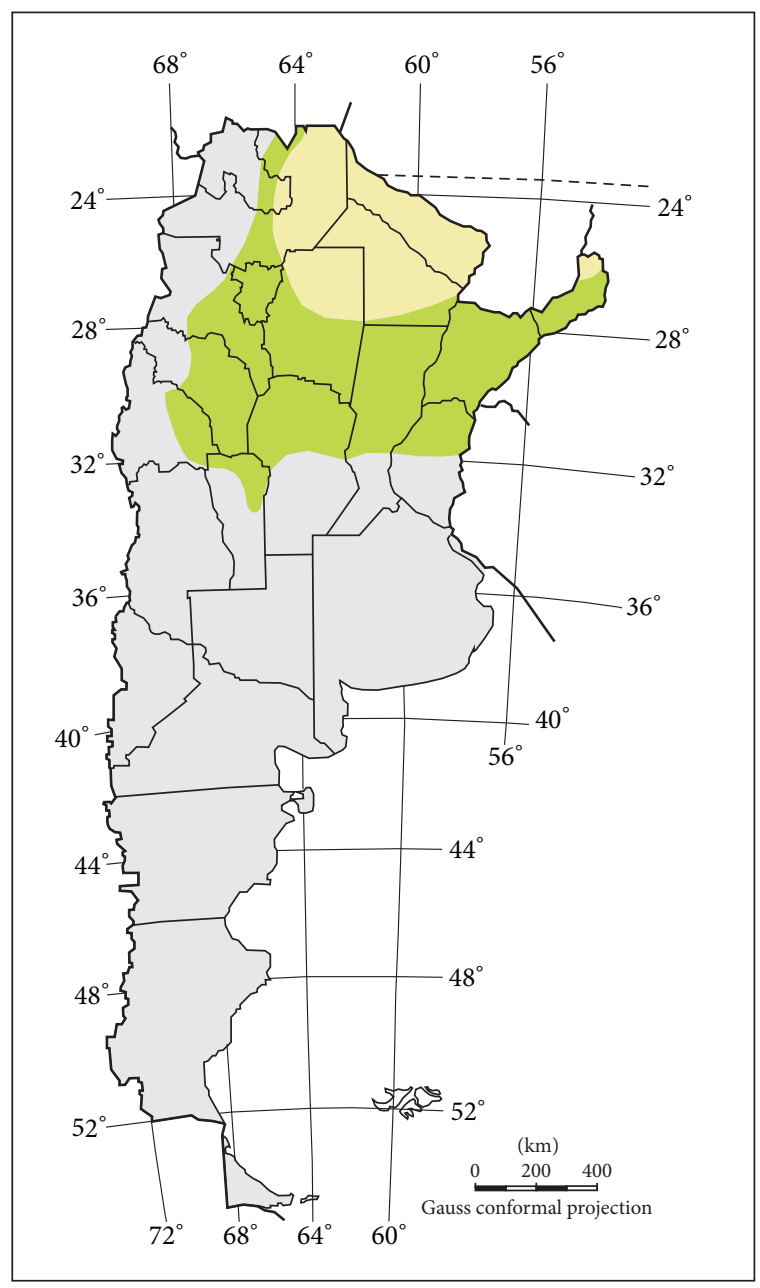

Marginal area: $>22^{\circ} \mathrm{C}$

Suitable area: $22-17,5^{\circ} \mathrm{C}$

Non suitable area: $<17,5^{\circ} \mathrm{C}$

FiguRE 6: Winter mean maximum temperature.

suitable, suitable, suitable area with constraints (under drysubhumid, semiarid, and arid regime) and under irrigation, marginal, and nonsuitable areas.

\section{Discussion}

As can be observed in Figure 9, there is no optimal agroclimatic area for argan cultivation because, in the optimal zone, the minimum temperature of the coldest month is never below $7^{\circ} \mathrm{C}$ [25]. In the areas with agroclimatic suitability (suitable and very suitable), this index is between 3.5 and $7^{\circ} \mathrm{C}$. A very suitable area was described, which covers a large portion of the province of La Rioja and a small part of Catamarca. The suitable areas cover part of the provinces of Catamarca, La Rioja, Córdoba, and San Luis and small areas in Tucumán, Santiago del Estero, and Salta. To the west of the very suitable area, there is a suitable area with constraints under semiarid regime that comprises part of the provinces of San Juan, La Rioja, and San Luis. A suitable area 


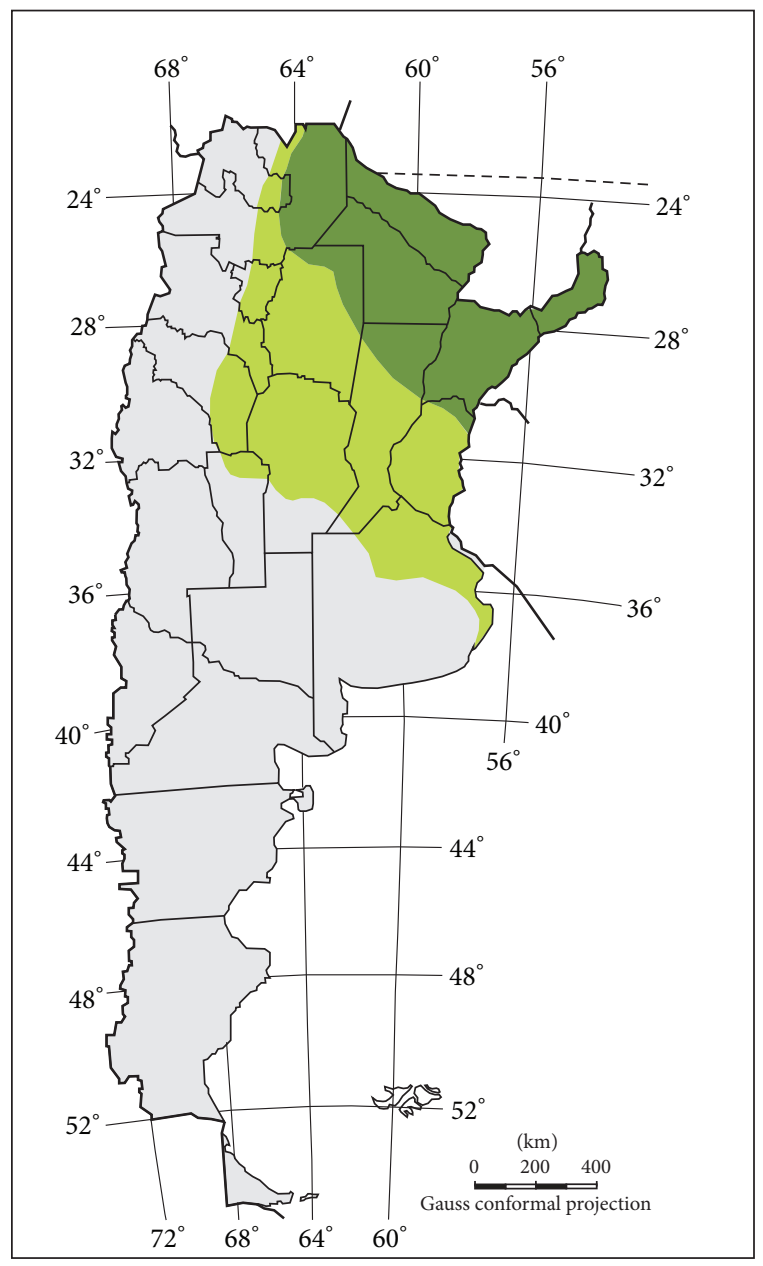

Optimal area: $>7^{\circ} \mathrm{C}$

Suitable area: $7-3,8^{\circ} \mathrm{C}$

Non suitable area: $<3,8^{\circ} \mathrm{C}$

FIgURE 7: Minimum temperature of coldest month.

with constraints under dry-subhumid regime is present in the center of the provinces of Catamarca and Salta. Under arid conditions there is another area classified as suitable with constraints which covers parts of the provinces of San Mendoza, San Juan, and La Rioja. A suitable area with constraints under irrigation is in the provinces of San Juan, La Rioja, and Catamarca, and small ones can be found in Mendoza and San Luis. The suitable and very suitable zones delimited for argan in Argentina are characterized by low and variable rainfall (100 to $400 \mathrm{~mm}$ ) and mild winter temperatures. The dry season is inordinately long, resulting in a short growing season. These are areas with mostly lithosols and regosols soils, associated with saline soils on lowlands.

The argan tree does not exist in Argentina and, consequently, there are no commercial plantations that can be used to compare the agroclimatic zones delineated in this paper.

According to [13], this species flourishes in desert or arid (Bw), steppe or semiarid (Bs) climates, between 20 and

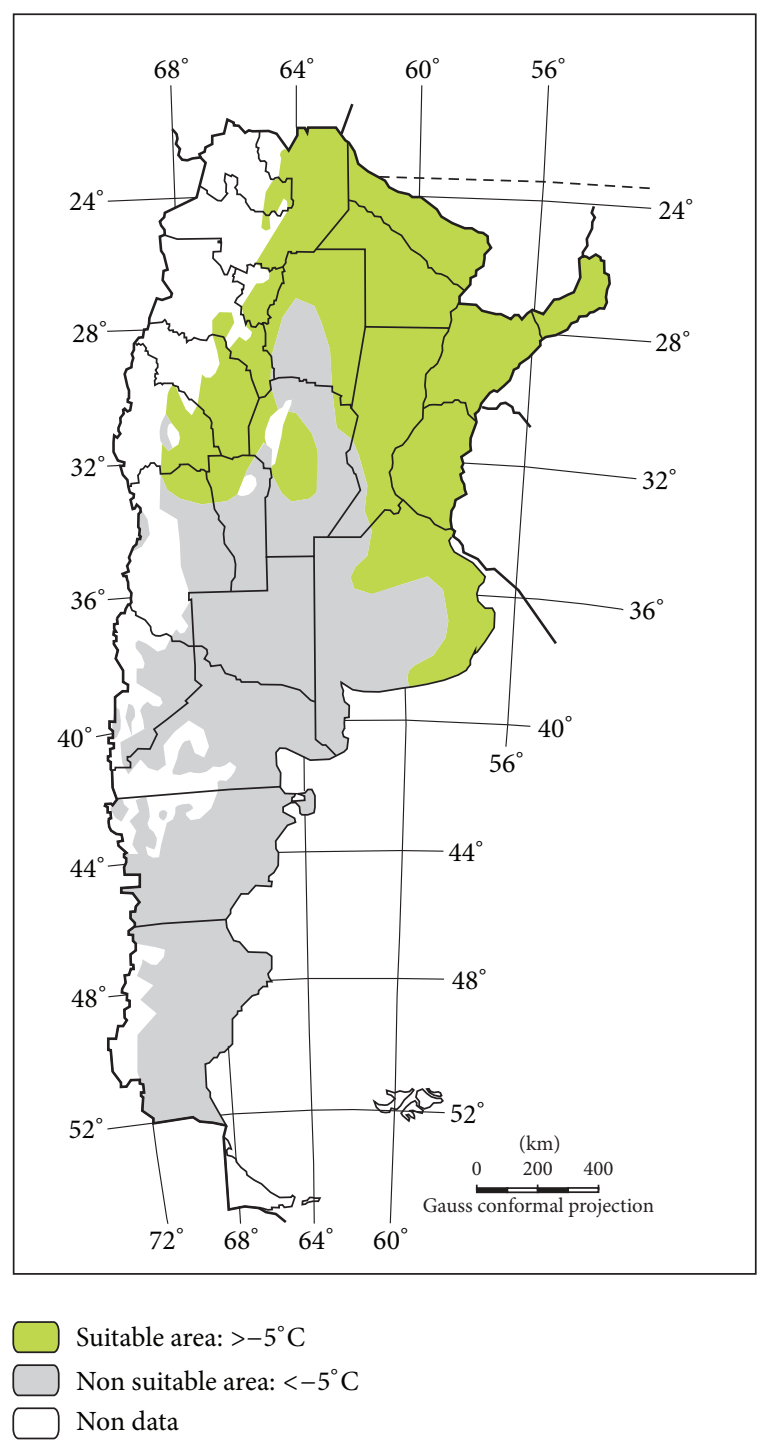

FIGURE 8: Mean annual minimum temperature.

$32^{\circ}$ latitude. This agrees with the agroclimatic zoning map presented in this paper, since the suitable area reaches the north of San Luis province (approximately $33^{\circ} \mathrm{S}$ ).

However, Discover Life [26] cites the species in a larger latitudinal range. For example, it mentions a preserved specimen in Arizona, USA, at $34.5^{\circ} \mathrm{N} / 111^{\circ} \mathrm{W}$; in Spain at $37.5^{\circ} \mathrm{N} / 9^{\circ} \mathrm{W}, 38.21^{\circ} \mathrm{N} / 10.25^{\circ} \mathrm{W}$, and $40.5^{\circ} \mathrm{N} 3^{\circ} \mathrm{W}$; in United Kingdom at $52.5^{\circ} \mathrm{N} / 3^{\circ} \mathrm{W}$; in Kenya at $1.5^{\circ} \mathrm{N} / 39^{\circ} \mathrm{E}$; and in Morocco at $31.5^{\circ} \mathrm{N} / 9^{\circ} \mathrm{W}$ and $31.5^{\circ} \mathrm{N} / 3^{\circ} \mathrm{W}$.

The GBIF [27] cites only 34 occurrences with georeferenced data. Some of them are in the following countries: Algeria $\left(1.33^{\circ} \mathrm{N} / 36.16^{\circ} \mathrm{W}\right)$, Netherlands $\left(52.25^{\circ} \mathrm{N} /\right.$ $\left.5.60^{\circ} \mathrm{E}\right)$, USA $\left(34.14^{\circ} \mathrm{N} / 118.05^{\circ} \mathrm{W}\right.$ and $\left.34.00^{\circ} \mathrm{N} / 118.00^{\circ} \mathrm{W}\right)$. In Spain, there are specimens in Alicante, Murcia, Gran Canaria (Canary Islands), and Barcelona $\left(38,06^{\circ} \mathrm{N} / 1,17^{\circ} \mathrm{W}, 38,42^{\circ} \mathrm{N} /\right.$ $0,42^{\circ} \mathrm{W}, 27,10^{\circ} \mathrm{N} / 15,10^{\circ} \mathrm{W}, 38,41^{\circ} \mathrm{N} / 0,42^{\circ} \mathrm{W}, 38,33^{\circ} \mathrm{N} / 0,54^{\circ} \mathrm{W}$, $38,51^{\circ} \mathrm{N} / 0,53^{\circ} \mathrm{W}, 38,41^{\circ} \mathrm{N} / 0,42^{\circ} \mathrm{W}, 41,10^{\circ} \mathrm{N} / 2,10^{\circ} \mathrm{E}$, and $41,36 \mathrm{~N}^{\circ}$ / $\left.2,16^{\circ} \mathrm{E}\right)$. The rest of the citations correspond to Morocco 


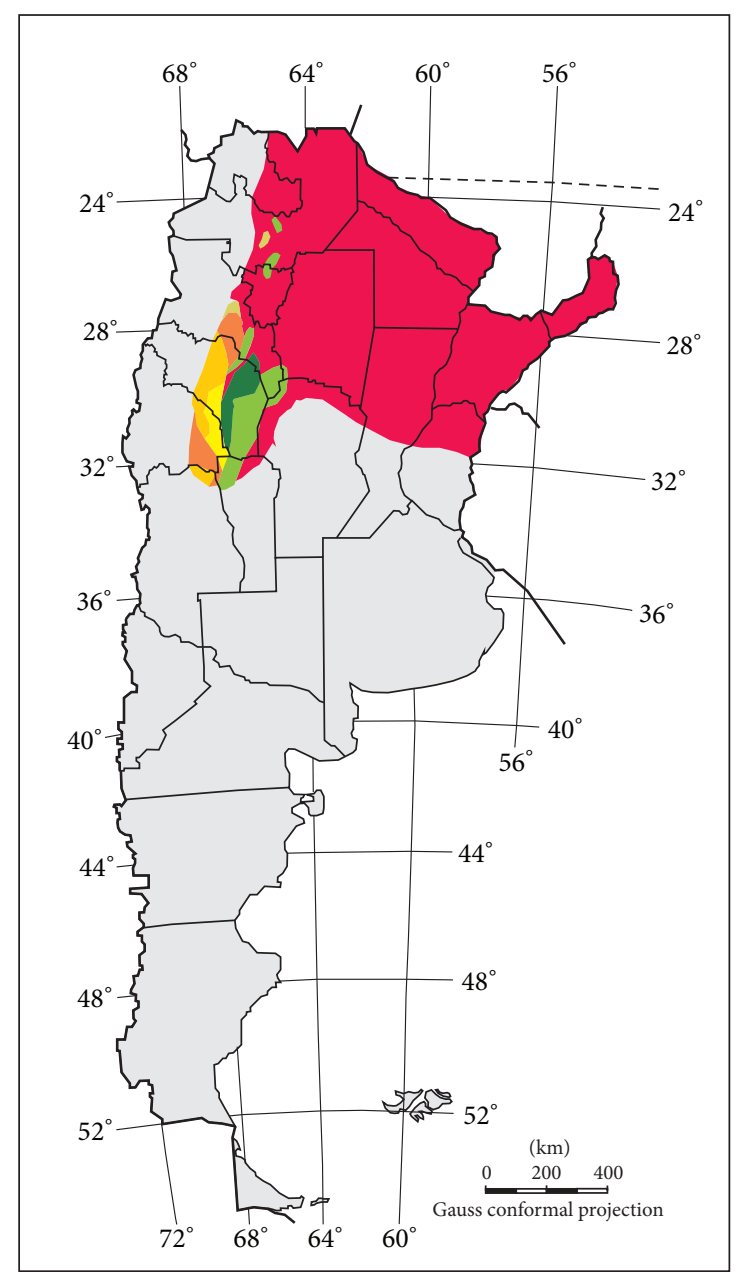

Very suitable area

Suitable area

Suitable area with constraints (dry-subhumid regime)

Suitable area with constraints (semiarid regime)

Suitable area with constraints (arid regime)

Suitable area with constraints under irrigation

Marginal area

Non suitable area

FIGURE 9: Agroclimatic zoning for the argan tree.

$\left(30,53^{\circ} \mathrm{N} / 7,89^{\circ} \mathrm{W}, 30,79^{\circ} \mathrm{N} / 8,38^{\circ} \mathrm{W}, 29,70^{\circ} \mathrm{N} / 9,92^{\circ} \mathrm{W}, 30,82^{\circ} \mathrm{N} /\right.$ $8,40^{\circ} \mathrm{W}, 30,68^{\circ} \mathrm{N} / 8,17^{\circ} \mathrm{W}, 29,42^{\circ} \mathrm{N} / 9,44^{\circ} \mathrm{W}, 30,37^{\circ} \mathrm{N} / 9,70^{\circ} \mathrm{W}$, $30,62^{\circ} \mathrm{N} / 8,09^{\circ} \mathrm{W}, 29,75^{\circ} \mathrm{N} / 9,28^{\circ} \mathrm{W}$, etc.).

Argan is a thermoxerophile and its edaphic requirements are scarce [28]. It adapts well to hostile environments, and it can even be irrigated with salt-rich water [29]. Consequently, argan can be used as a repopulation species in semiarid and arid zones.

The suitable and very suitable areas for argan largely coexist with the Argentine olive tree cultivation region. Currently, the olive industry has been curtailed due to rising production costs (approximately $40 \%$ annually) and low foreign currency (dollar) values. As a result, many growers have ceased investing and olive farms have been abandoned. The harvested area for olives in Argentina has been decreasing permanently. Argan cultivation could reconvert the olive areas by interspersing argan and olive trees to reach a more lucrative production per hectare.

In the future, farmers could combine horticultural species cropping, some olive trees, vegetables and livestock (mainly goats) in association with the argan tree, and beekeeping. These areas have regular drought periods, which could be mitigated by argan tree since it not only provides forage for goats but also produces argan oil for local consumption and for sale.

Considering the increase in arid conditions worldwide, together with the prediction for fewer rainfalls, argan trees could be used for greenery purpose and to reduce climate change effect.

The agroclimatic suitability map presented is indicative because climate data spanning 30 years was used rather than data for a specific year. As a result, in locations where topographic and geographic traits significantly alter the microclimate, specific areas where the species may be grown could be unknowingly disregarded. Notwithstanding, this is pioneering work because the agroclimatic zoning for the argan tree in Argentina has never been done before.

\section{Conclusions}

The climatic requirements and tolerances of the argan tree have been outlined in relation to the environmental conditions of their natural habitat. An agroclimatic zoning model was developed. Basic data in determining this similarity were the amount of annual rainfall, the annual temperature, the annual minimum temperature, the winter maximum temperature, the minimum temperature of the coldest month, the mean annual minimum temperature, and the annual maximum temperature.

The successful introduction of this species in Argentina depends essentially on the degree of similarity of climate in the natural area to that of the new areas with agroclimatic suitability.

There are no optimal zones for the argan tree in Argentina. Very suitable, suitable, and marginal areas for this species were delimitated.

\section{Conflicts of Interest}

The authors declare that they have no conflicts of interest.

\section{Acknowledgments}

This research was supported by the National Council of Scientific and Technical Research (CONICET) of Argentina.

\section{References}

[1] T. J. Lybbert, C. B. Barrett, and H. Narjisse, "Market-based conservation and local benefits: The case of argan oil in Morocco," Ecological Economics, vol. 41, no. 1, pp. 125-144, 2002. 
[2] F. Msanda, A. El Aboudi, and J. P. Peltier, "Biodiversité et biogéographie de l'arganeraie marocaine," Cahiers Agricultures, vol. 14, no. 4, pp. 357-364, 28 May 2016, http://www.jle.com/fr/ revues/agr/e-docs/biodiversite_et_biogeographie_de_larganeraie marocaine_266250/article.phtml?tab=texte.

[3] O. M'Hirit, M. Benzyane, F. Benchekroun, S. M. El Yousfi, and M. Bendaanoun, L'Arganier. Une espèce fruitière à usages multiples, P. Mardaga, Ed., Sprimont, Belgique, 1998.

[4] D. Rivera and J. B. Ruiz, "Argania spinosa L (Skeel) Sapotaceae. Subespontánea en la Península Ibérica," Anales del Jardín Botánico de Madrid, vol. 44, no. 1, p. 173, 1978.

[5] A. Benabid, Flore et écosytèmes du Maroc: évaluation et préservation de la biodiversité, Ibis Press, Paris, France, 2000.

[6] C. Orwa, A. Mutua, R. Kindt, R. Jamnadass, and S. Anthony, "Agroforestree Database: a tree reference and selection guide version 4.0," 28 December 2015, http://www.worldagroforestry .org/sites/treedbs/treedatabases.asp.

[7] Z. Charrouf and D. Guillaume, "Argan oil: occurrence, composition and impact on human health," European Journal of Lipid Science and Technology, vol. 110, no. 7, pp. 632-636, 2008.

[8] N. El Benni and S. Reviron, Geographical Indications: Review of Seven Case-Studies World Wide; NCCR Trade Regulation, Working Paper No 2009/15, Swiss National Centre of Competence in Research, 2009, http://phasel.nccr-trade.org/ images/stories/publications/IP5/GI_Case-studies_2009.pdf.

[9] ITIS, “Catalogue of Life: 2014 Annual Checklist," 26 November 2015, http://www.catalogueoflife.org/annual-checklist/2014/details/species/id/9714131.

[10] JP. Peltier, G. Carlier, and A. El Aboudi, "Evolution journalière de l'état hydrique des feuilles d'arganier (Argania spinosa L. Skeels.) sous bioclimat aride à forte influence océanique (plaine du Souss, Maroc)," Acta Oecol, vol. 11, no. 5, pp. 643-668, 1990.

[11] Z. Charrouf and D. Guillaume, "Argan Oil," Alternative Medicine Review, vol. 16, pp. 275-279, 2011, http://altmedrev .com/publications/16/3/275.pdf.

[12] Y. le Polain de Waroux and E. F. Lambin, "Monitoring degradation in arid and semi-arid forests and woodlands: The case of the argan woodlands (Morocco)," Applied Geography, vol. 32, no. 2, pp. 777-786, 2012.

[13] FAO, “Ecocrop," (1993-2007) Available at: http://ecocrop.fao.org/ ecocrop/srv/en/home Accessed 26 June 2015.

[14] F. Bani-Aameur and J. Sipple-Michmerhuizen, "Germination and seedling survival of Argan (Argania spinosa) under experimental saline conditions," Journal of Arid Environments, vol. 49, no. 3, pp. 533-540, 2001.

[15] Y. Mizrahi and A. Nerd, "New Crops as a Possible Solution to the Troubled Israeli Export Market," in Progress in New Crops, J. Janick and J. E. Simon, Eds., pp. 56-64, ASH Press, Alexandria, VA, USA, 1996.

[16] Z. Bouzoubaâ and A. El Mousadik, "Temperature drought and salt effect on Arganiaspinosa (L.) Skeels seed germination," Acta Botanica Gallica, vol. 150, no. 3, pp. 321-330, 2 June 2016.

[17] A. Zahidi and F. Bani-Aameur, "Germination des amandes d'arganier (Argania spinosa (L.) Skeels): effet du génotype, de la date de semis et de l'année de récolte," Annales de la Recherche Forestiere au Maroc, vol. 30, pp. 2-16, 1997.

[18] M. Zunzunegui, F. Ain-Lhout, J. Jáuregui et al., "Fruit production under different environmental and management conditions of argan, Argania spinosa (L.)," Journal of Arid Environments, vol. 74, no. 10, pp. 1138-1145, 2010.
[19] Z. Bouzoubaâ and A. El Mousadik, "Effet de la température, du déficit hydrique et de la salinité sur la germination de l'Arganier, Argania spinosa (L.) Skeels," Acta Botanica Gallica, vol. 150, no. 3, pp. 321-330, 2003.

[20] H. N. Le Houerou, The desert and arid zones of northern Africa, M. Evenari and D. W. Goodal, Eds., vol. 74 of Hot deserts and arid shrublands, Elsevier, Amsterdam, Netherlands, 1986.

[21] R. Michalet, Une approche synthétique biopédoclimatique des montagnes méditerranéennes: exemple du Maroc septentrional, Doctorat université Joseph Fourier, Grenoble I, France, 28 May 2016, http://cat.inist.fr/?aModele $=$ afficheN\&cpsidt $=148671$.

[22] A. Benabid, Bref aperçu sur la zonation altitudinale de la végétation climatique du Maroc. Ecología Mediterranea VIII, 26 June 2016, http://ecologia-mediterranea.univ-avignon.fr/ uploads/media/Ecologia_mediterranea_1982-8_1-2.pdf.

[23] S. M. El Yousfi and F. Benchekroun, "La dégradation forestière dans le sud marocain, exemple de l'arganeraie d'Admine (Souss) entre," Annales de la Recherche Forestiere au Maroc, vol. 26, pp. 1969-1986, 1992.

[24] M. R. Tarrier and M. Benzyane, L'arganeraie marocaine se meurt: problématique et bioindication. Revue Sécheresse en ligne, 28 April 2016, http://www.secheresse.info/article.php3?id_article= 228.

[25] P. Quézel and F. Médail, Écologie et biogéographie des forêts du Bassin méditerranéen, Collection Environnement, Elsevier, Paris, France, 2003.

[26] Discover life (N/D), Argania spinosa, 26 March 2016, http://www.discoverlife.org/mp/20m?kind=Argania+spinosa.

[27] GBIF, Global Biodiversity Information Facility (N/D), Argania spinosa, 26 August 2015, http://www.gbif.org/occurrence/search? taxon_key=5333832\&HAS_COORDINATE=true\&HAS_GEOSPATIAL_ISSUE $=$ false \&offset $=20$.

[28] A. Homrani Bakali, Essai d'installation et de suivi de comportement de l'arganier (argania spinosa) dans le contexte aride de Tafilalet, Actes du Premier Congrès International de l' Arganier, Décembre 2011, http://www.inra.org.ma/Docs/actesarganier/arganier309318.pdf.

[29] D. Enneking, "Argan (Argania spinosa)," Australian New Crops Newsletter, vol. 10, no. 1-2, 1998. 


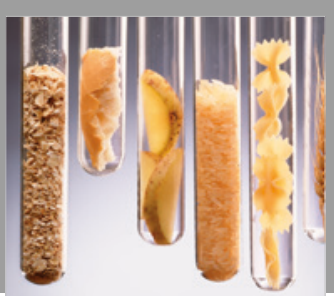

International Journal of Food Science

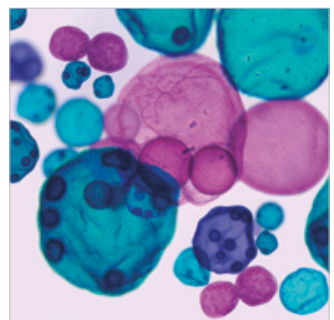

International Journal of Microbiology
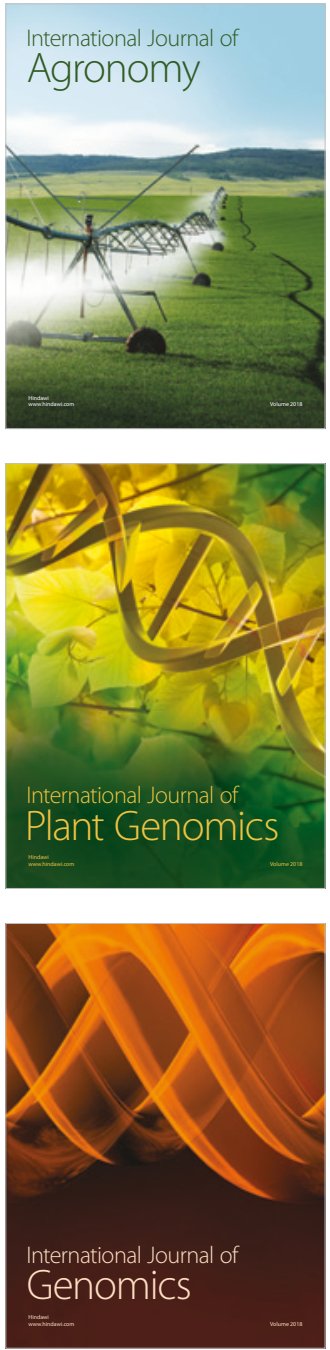

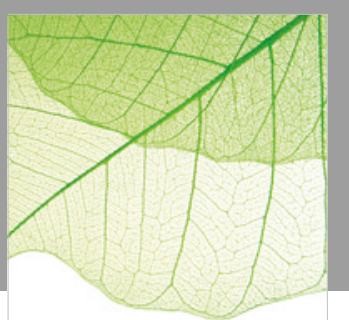

Journal of Botany
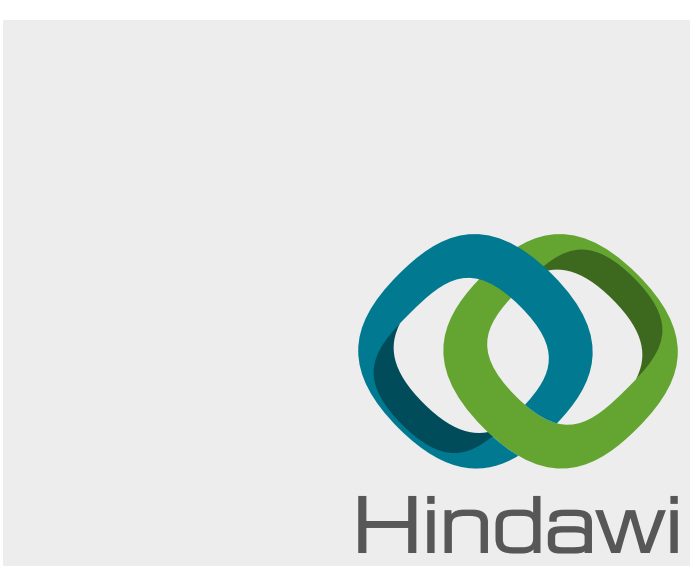

Submit your manuscripts at

www.hindawi.com
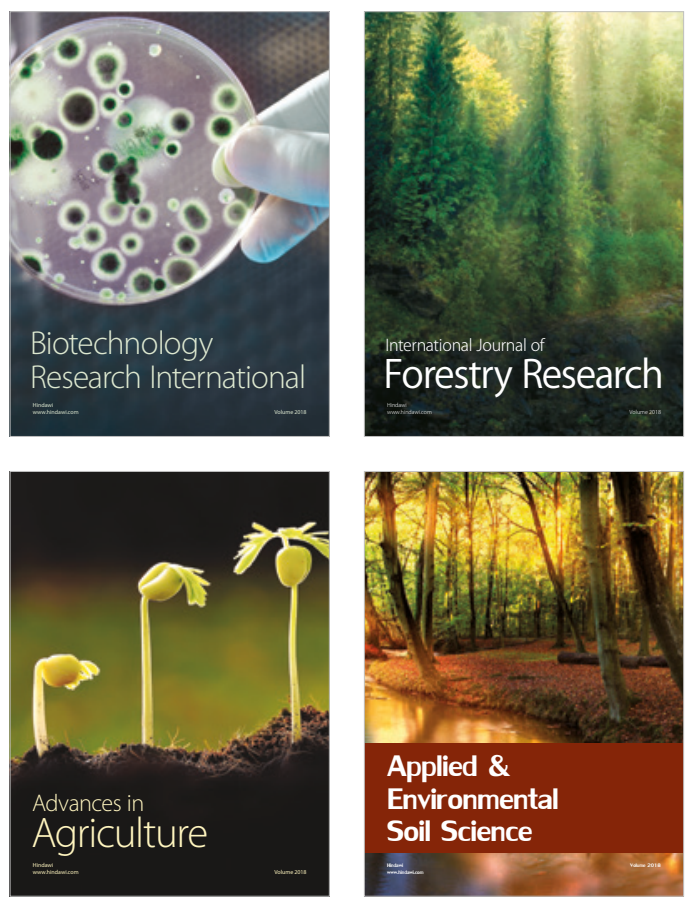

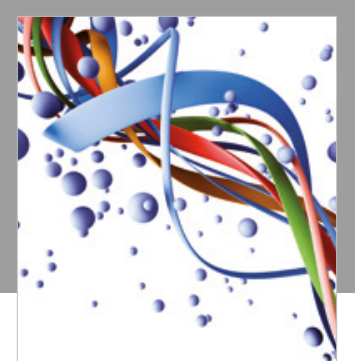

Scientifica

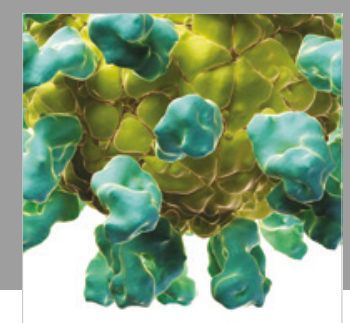

Veterinary Medicine International

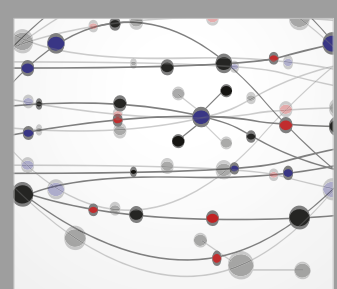

The Scientific World Journal
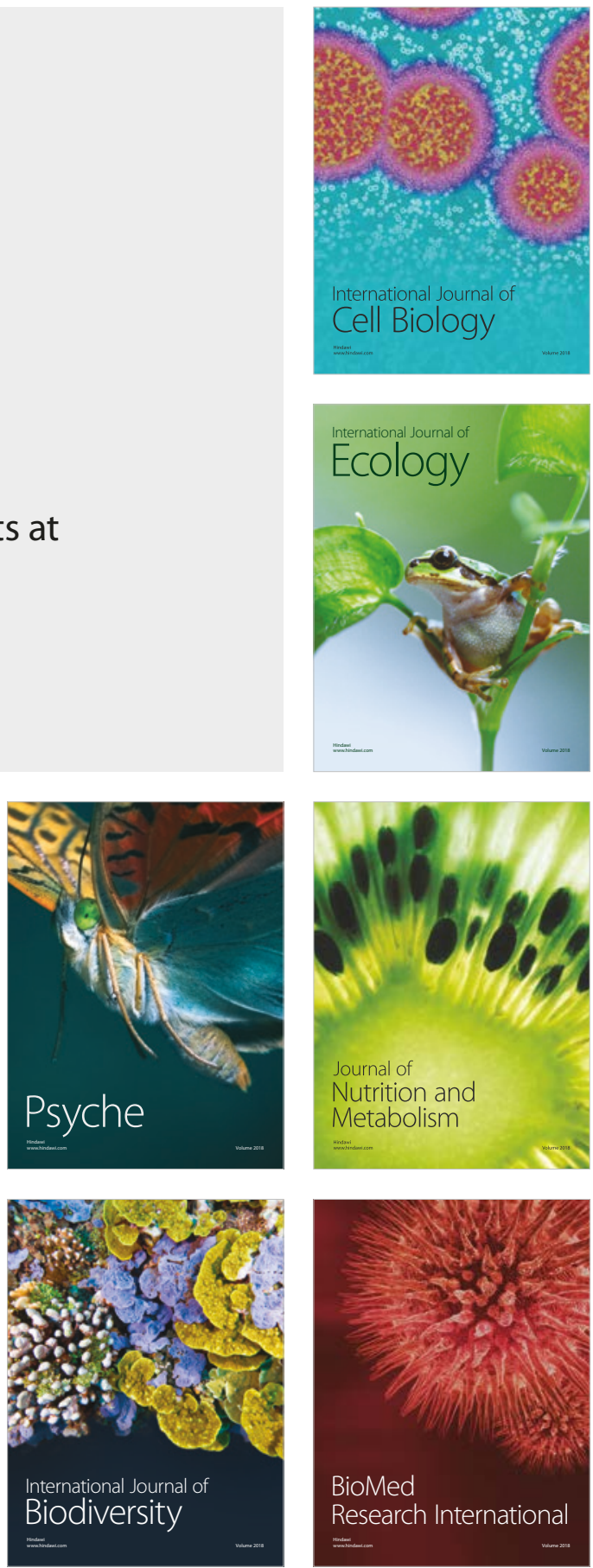